\title{
Elektroniczna dokumentacja europejskiego dziedzictwa piśmienniczego Litwy i Polski
}

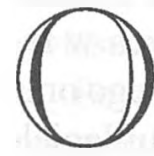
bywatele zjednoczonej Europy XXI wieku w oficjalnych dokumentach Unii Europejskiej nazywani są społeczeństwem informacyjnym. ${ }^{1}$ Propozycja takiego określenia wynika zarówno z ofert informacyjnych spowodowanych postępem techniki, jak i z nowych potrzeb rozwoju społeczeństwa, nazywanego równocześnie „studiującym” [Learning Society]. ${ }^{2} Z$ miany te rodzą się sukcesywnie w następstwie poszerzenia dostępu elektronicznego do informacji typu Internet, stron WWW, poczty elektronicznej, baz danych multimedialnych różnego typu, zakresu i zasięgu; wydawnictw elektronicznych, a zwłaszcza czasopism, których w odniesieniu do polskich spraw można naliczyć z końcem 1997 r. więcej niż pół tysiąca tytułów. ${ }^{3}$ Społeczeństwo zbliżającego się przełomu stuleci będzie miało też nowe potrzeby intelektualne. Przyczyni się do tego pogoń za nowymi miejscami pracy i konieczność przekwalifikowywania zawodowego, przybywanie wolnego czasu ze względu na liczbę osób w wieku emerytalnym (wcześniejsze emerytury), redukcje w pracy, wzrost bezrobocia, etc. Rozwiną się zainteresowania hobbystyczne (udział np w konkursach), a i też badania naukowe, które coraz częściej będą przywilejem wieku nie tylko czynnego zawodowo.

W tych rozbudzanych zainteresowaniach przełomu wieków nie powinno zabraknąc problemów ochrony europejskiego i narodowego dziedzictwa piśmienniczego. Im grono badaczy i entuzjastów tej problematyki będzie szersze i bardziej zróżnicowane tym łatwiej będzie wydobyć cechy multikulturalne, tak ważne w perspektywie europejskiej, pożyteczne dla wielu narodów, ukazujące jak szukać we wspólnej przeszłości tego co łączy, a nie dzieli ludzkość. ${ }^{4}$

W moim przekonaniu punktem podstawowym dla tego typu badań musi stać się sporządzenie rejestru zabytków narodowego dziedzictwa piśmien- 
niczego, ważnych dla wielu kultur. $\mathrm{W}$ takim aspekcie należy docienić tym bardziej ideę konferencji PTB w 1997 r.: „Z problemów ochrony europejskiego i narodowego dziedzictwa piśmienniczego", która ma za zadanie podsumować bardzo interesujące informacje o postępie w pracach, ich ideach i warunkach, w nawiązaniu do zbiorów znajdujących się za granicą wschodnią Polski.

Dziękując za zaproszenie na obrady w imieniu Oddziału PTB w Krakowie, pragnę dodać przyczynek związany z Litwą i nowoczesnymi technika$\mathrm{mi}$, pozwalającymi na bezkonfliktowe przekraczanie barier czasu i granic państw. Oba aspekty są charakterystyczne dla badań prowadzonych w ramach Oddziału w Krakowie Polskiego Towarzystwa Bibliologicznego oraz Instytutu Bibliotekoznawstwa i Informacji Naukowej Uniwersytetu Jagiellońskiego, z którego większość członków się wywodzi. Z Wilnem łączy uczelnię krakowską wieloletnia umowa współpracy bezpośredniej między najstarszymi w Polsce i na Litwie uniwersytetami, podtrzymywana od ponad 20 lat stałą, dobrze się układającą i efektywną współpracą w zakresie bibliotekoznawstwa i informacji naukowej. ${ }^{5}$ W prowadzanie nowoczesnych technik w badaniach i nauczaniu, związanymi z biblioteką, książką i informacją naukową jest stała, powszechnie znaną troską kadry Instytutu Bibliotekoznawstwa i Informacji Naukowej Uniwersytetu Jagiellońskiego. ${ }^{6}$

W Wilnie, jak ogólnie wiadomo, są przechowywane najbogatsze zbiory rękopisów na Litwie. Dokumentacja ta posiada znaczenie ważne dla zjednoczonej Europy. Wśród nich znajduje się wiele, będących przykładem integracji kulturalnej od wieków wielu narodów, a zwłaszcza polskiego i litewskiego. Udostępnienie o nich elektronicznej informacji, zaplanowane pod moim kierunkiem na lata 1997-1998 przez zespól pracowników Instytutu Bibliotekoznawstwa i Informacji Naukowej Uniwersytetu Jagiellońskiego, zostało wyróżnione wsparciem środkami Komitetu Badań Naukowych. ${ }^{7}$ Realizacja tej prekursorskiej inicjatywy będzie miała ważne znaczenie zarówno dla Polski, jak i międzynarodowe. O potrzebie takiej informacji świadczą zapytania kierowane do Krakowa przez pocztę tradycyjną i elektroniczną z całego świata po opublikowaniu w 1993 r.pod moją redakcją pracy zbiorowej Przewodnik po zbiorach rękopisów w Wilnie.

Podjęcie prac nad tym informatorem było integralnie związane $\mathrm{z}$ powstaniem bazy danych w programie MicrolSIS, w latach 80 . bezpłatnie wprowadzonym na rynek przez UNESCO dla krajów uwolnionych od opieki ZSRR. ${ }^{8}$ To międzynarodowe przedsięwzięcie, firmowane przez Polskie Towarzystwo Bibliologiczne Oddział w Krakowie i Uniwersytet Jagielloń- 
ski było sponsorowane przez doceniająca pokojowe idee demokratyczne Fundację im. Stefana. Batorego i Wydział Spraw Społecznych Urzędu Wojewódzkiego w Krakowie. Skąd tyle zainteresowania dla podjętych prac? Inspiracja płynęła nie tylko $\mathrm{z}$ wagi samego tematu, ale i $\mathrm{z}$ formy organizacyjnej, będącej testem na możliwość pokojowej współpracy w nowych układach politycznych po 1989 r. W tym duchu - we wstępie do tej książki oceniałam przydatność informacji o polsko-litewskim fragmencie europejskiego dziedzictwa kulturalnego, fascynującym też dla mieszkańców dzisiejszej Ukrainy, Białorusi, Łotwy, Estonii, Rosji, Karaimów, Żydów, etc., zwłaszcza w relacjach mniejszości narodowych.

Powróćmy do tego tekstu: „Swobodny przepływ myśli naukowej na pewno sprzyja zjednoczeniu Europy. [...] Druga Wojna Światowa i jej następstwa spowodowały wiele przemieszczeń księgozbiorów, dezaktualizację informacji, nie do odrobienia straty wojenne, między innymi w źródłach do badań naukowych. Bilans tych strat nie został dotąd ukończony. Niezależnie jednak od ustalania i egzekwowania roszczeń należy ułatwić uczonym dostęp do aktualnej informacji o zbiorach - tak ważny dla prawidłowego rozwoju nauki. Zanim techniki komputerowe zastąpią tradycyjne, drukowane przewodniki po zbiorach - wydawanie takich opracowań, zwłaszcza w krajach dawniej ,za żelazną kurtyną” - wydaje się nieodzowne. Środowisko naukowe upomina się zarówno o informację dotyczącą pojedynczych instytucji, jak i przeglądową o zbiorach wielu instytucji w miejscowościach ważnych dla polskiej kultury i nauki, czy też regionalną, względnie ogólnopaństwową. Zainteresowanie zbiorami rośnie, gdy materiały ujęte w opracowaniach mogą się stać podstawą badań ważnych dla wielu narodów. Nauturalnie każdy kraj specjalnie dba o dostęp do informacji m.in. źródłowej u najbliższych sąsiadów. Splatająca się w toku dziejów historia znajduje przecież odbicie w dokumentach - świadkach wydarzeń. Kolekcje archiwalne i biblioteczne są znakomitymi rzecznikami prawdy historycznej, zawierają bowiem dowody rozwoju nauki, kultury, polityki, a też przyjaźni czy waśni między społecznościami; pozwalają na wyjaśnienie genezy wydarzeń, odszukanie motywacji, zrozumienie skutków.

Swobodne czerpanie w celach naukowych z bogactwa zasobów rękopiśmiennych nabiera specjalnego wyrazu, gdy miejscem ich przechowywania jest Miasto - Legenda. Takim miastem zarówno dla Polaków jak i Litwinów, symbolem „Obojga Narodów”, jest na pewnoWilno. [...]. Dla podkreślenia przyjaznych motywacji Przewodnika po zbiorach rękopisów w Wilnie [...] zdecydowano opisy zamieszczać w języku polskim oraz litewskim."9 
Założenie okazało się słusznym i w rezultacie do dzisiaj opracowanie jest nie tylko pierwszym powojennym tego typu wydawnictwem, ale i jedynym udostępniającym w obu narodowych językach łączną informację o najświetniejszych zespołach rękopisów w Wilnie. Analogiczną rolę, na miarę potrzeb przełomu wieków, będzie pełnić planowana na 1997/98 r. baza danych w Internecie.

Publikacja Przewodnik po zbiorach rękopisów w Wilnie objęła 1561 zespołów, które liczą często setki jednostek inwentarzowych. Książka powstała jako polsko-litewska praca zbiorowa pracowników pięciu instytucji w Wilnie: Litewskiego Państwowego Archiwum Historycznego [Lietuvos Valstybinio Istorijos Archyvas - (766 zespołów), Biblioteki Litewskicj Akademii Nauk [Lietuvos Mokslu Akademijos Centrine Biblioteka] - (325 zespołów), Biblioteki Uniwersytetu Wileńskiego [Vilniaus Universitetas Moksline Biblioteka] - (232 zespoły), Biblioteki Narodowej [Lietuvos Nacionaline Martyno Mazvydo Biblioteka] - (174 zespoły) i częściowo - Litewskiego Państwowego Archiwum Akt Nowych [ Lituvos Centrinis Valstybinis Archyvas] - (60 zespołów). Opisy sporządzone zostały w języku polskim i litewskim, natomiast dla indeksów (nazwisk, instytucji, miejscowości ), informacji o instytucjach i losach zbiorów podstawowym jest język polski, co wymagało zresztą nakładu olbrzymiej pracy redakcyjnej. Uzupełniają opracowanie konkordancje numerów inwentarzy litewskich i Przewodnika po zbiorach rękopisów w Wilnie oraz wykazy publikowanych bądź w maszynopisie katalogów tych zbiorów. Równolegle opracowana baza danych MicroISIS posiada odpowiednie do indeksów możliwości wyszukiwania, a nawet trochę poszerzone. Naturalnie książka jak i baza danych zawiera informację o całości zbiorów znajdujących się w archiwalnych instytucjach Wilna, a nie tylko o polonikach, co czyni jej zakres informacyjny bardziej interesującym dla użytkowników.

Ze względu na ogłoszenie drukiem w Rzymie w 1994 r. osobnej mojej rozprawy nt Polonica w bibliotekach litewskich - tylko w skrócie zasygnalizuję obfitość dokumentacji polskiej w tych zbiorach, świadczącej jakże często o wspólnych, europejskich korzeniach kulturalnych Polski i Litwy oraz innych nacji. ${ }^{10}$

Spróbuję ukazać te materiały wg obecnych miejsc przechowywania: * Litewskie Państwowe Archiwum Historyczne - jest najobfitszym źródłem dokumentów. Zawiera Archiwum Trybunału Wielkiego Księstwa Litewskiego (częściowo wywiezione przez Rosjan w 1914 r.); Archiwa sądów wileńskich, akta Litewskiej Generalnej Konfederacji Targowickiej, Litew- 
skiej Komisji Skarbowej, Litewskiego Trybunału Skarbowego (dokumenty dóbr ziemskich), Archiwum Centralne (od 1852 r.) Generalnego Gubernatorstwa Wileńskiego, Muzeum Murawjewa (utworzone w 1892), Towarzystwa Przyjaciól Nauk w Wilnie. Tym dokumentom o znaczeniu multikulturalnym, ważnych zarówno dla Polaków, Litwinów, Rusinów,w sumie dla kultury łacińskiej, towarzyszą tam wielotysięczne akta różnych kościołów, cechów, rodowe (w tym ok. 30 znacznych polskich rodów).

* Biblioteka Litewskiej Akademii Nauk szczyci się zbiorami Kapituły Wileńskiej, zbiorem aktów na pergaminie, autografów historycznych osobistości, aktami dóbr ziemskich, majątków klasztornych, kościelnych, biskupstw, arcybiskupstw (katolickich, ewangelicko-reformowanych, kalwińskich\}, cmentarza na Rossie i Bernardynów w Wilnie, oraz setkami dokumentów biograficznych o wieloaspektowym, międzynarodowym znaczeniu. * Biblioteka Uniwersytetu Wileńskiego chroni dokumenty pergaminowe (700 poz. inw.), rękopisy cerkiewnosłowiańskie, dokumenty związane z wielonarodowościowym szkolnictwem w Wilnie i na Litwie, dossier profesorów i wychowanków, dzieje uczelni, akta z okresu kuratorii ks. Adama Jerzego Czartoryskiego, skonfiskowane archiwalia uczestników powstań, akta miasta Wilna, towarzystw naukowo-oświatowych, dokumentację instytucji książki: drukarni, księgarń, bibliotek, wydawnictw, redakcji czasopism, oraz inne dokumenty ważne dla rozwoju nauki dawniej i obecnie.

* Litewska Biblioteka Narodowa im. Martyno Mazvydo zawiera autografy osobistości świeckich i kościelnych, dokumenty dóbr ziemskich, towarzystw, różnych organizacji politycznych, kulturalnych, społecznych.

* Litewskie Centralne Państwowe Archiwum Akt Nowych posiada żródła do historii szkolnictwa na Ziemi Wileńskiej: Kuratorium Szkolne Okręgu Wileńskiego (1922-1939), Departamentu Oświaty Tymczasowej Komisji Rządzącej Litwy Środkowej m.Wilna (1920-1922), Ministerstwa Wyznań Religijnych i Oświecenia Publicznego RP m. Wilna (1929-1931), akta poszczególnych szkół ${ }^{11}$ i tysiące innych aktów. Dokumenty szkół są testem na rozwój demokracji. Dokumenty majątkowe stanowią obecnie centralny punkt zainteresowania wydziedziczonych przez władzę sowiecką właścicieli różnych wyznań, profesji, narodowości.

Przewodnik po zbiorach rękopisów w Wilnie udostępnia pierwsze łączne informacje po II Wojnie Swiatowej o najznakomitszych zbiorach rękopisów w Wilnie, stanowiących ważne dziedzictwo kultury europejskiej.Należy wyrazić radość, że prace zostały zainspirowane w kręgu krakowskiego Oddziału Polskiego Towarzystwa Bibliologicznego i Uniwersytetu Jagielloń- 
skiego. Trzeba dodać, że podobnie prekursorskie zadanie zostało postawione dla rozpowszechnienia tej informacji w bazie danych przez Internet. Posiadać ona będzie rozszerzone możliwości wyszukiwawcze w porównaniu do cytowanej publikacji i bazy lokalnej MicroISIS.

Dla dalszej realizacji celów dokumentacyjnych i ułatwiania dostępu użytkownikom - marzą się multimedialne bazy danych, pozwalające na studiowanie pełnych tekstów dokumentów bez ograniczeń barierami czasu i przestrzeni, oczekiwane przez społeczeństwo europejskie przełomu wieków XX/ XXI. ${ }^{12}$ Dobrym wstępem do tej nieodzownej informacji powinna stać się anonsowana baza Internetowa. ${ }^{13}$ Jej użytkownicy będą mieli szansę na przełamanie róznych barier, ułatwienie pokojowego współuczestniczenia w badaniach naukowych, wskazanie właściwej drogi dla demokracji i tolerancji w badanich naukowych dawniej i dzisiaj, budowanie europejskiej perspektywy oceny wzlotów i upadków społeczeństwa w toku dziejów.

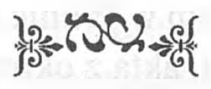

Przypisy:

${ }^{1}$ Informacja naukowa w krajach Unii Europejskiej. Wybrane zagadnienia prawne. Warszawa-Kraków 1997; Europe's Way to the Information Society. An Action Plan. Commission of the European Communities,Brussels,1994, maszyn. pow.

${ }^{2}$ Human Development: Competencies for the Twenty-First Century. Ed. by P.L. Ward, D.E. Weingand, Munchen 1997; I. Wormell, Succes Factors for Fee-Based Information Services, Helsinki 1996.

${ }^{3}$ M. Kocójowa, Czasopismo elektroniczne: nowa szansa dla rozwoju informacji naukowej. wykład inauguracyjny rok 1997/98, SD Papieska Akademia Teologiczna w Krakowie,maszyn; Electronic Future of Academic Libraries, ed. W. Pindlowa, Kraków 1997.

${ }^{4}$ On Crossroad of Information and Culture, IFLA 1998, Amsterdam

${ }^{s} \mathrm{O}$ współpracy UJ i UV zob.: Nowe kierunki $w$ dydaktyce i metodologi bibliotekoznawstwa $i$ informacji naukowej, Kraków 1993, Prace z Bibliotekoznawstwa i Informacji Naukowej z.1[3]. Zeszyty Naukowe UJ MCV; Libraries in Europe's Post-Communist Countries: Their International Context, ed. by M. Kocójowa, W. Zalewski, Kraków: PTB Kraków, 1996 (skrócona wersja w j.pol. 1995); I Kongres kultury niezawisłej Litwy. „Poradnik Bibliotekarza" 1990 nr 9 s. 33-35.; Głód ksiqżki polskiej na Wileńszczyźnie [w:] Dzieje mniejszości polskiej i Polonii w ZSRR, Kraków 1992, s.237-243. Zob. też czasopismo litewskie „Informacijos Mokslai" 1994 R.1 nr 1 s.69-79 oraz Knigotyra. Enciklopedinis zodynus, Vilnius 1997.

${ }^{6}$ Od 1995 r. Instytut BiIN UJ organizuje ogólnopolskie oraz międzynarodowe sesje naukowe związane $\mathrm{z}$ wprowadzaniem nowych technik do badań i nauczania. Pokłosiem ich jest sześć woluminów w serii Materiały Edukacyjne Bibliotekoznawstwa i Informacji Naukowej UJ: Edukacja z bibliotekoznawstwa $i$ informacji naukowej na poziomie wyższym w 
Polsce. Status i przyszlośc.,1995; Biblioteki w europejskich krajach postkomunistycznych w międzynarodowym kontekście (wybór), 1995; Modern Libraries and Librarianship in Poland, 1996; Libraries in Europe's..., 1996; Rynek pracy a studia bibliotekoznawstwa i informacji naukowej w Polsce, 1996; Swiatowa strategia edukacji bibliotekarzy i pracowników informacji naukowej, Krtaków 1998; Edukacja permanentna w międzynarodowej perspektywie [w druku].

7 Decyzja KBN nr 1230/W/DOT/DI/97 dot. rozbudowy i udostępniania baz danych o charakterze regionalnym i ogólnokrajowym w sieciach komputerowych. Projekt 1997-1998: „Rękopisy polskie w zbiorach wileńskich". W pracach zespołu pod kier. M.Kocójowej uczestniczyli: W. Szczęch, Ł. Bieńkowski, I. Ćwikilewicz, M. Jaskowska i K. Jaśko.

${ }^{8}$ Od 1986 Instytut INTE w Warszawie jest wyłącznym dystrybutorem licencjonowanego pakietu Mikro CDS/ISIS. W 1993 r. ogólna ilość użytkowników instytucjonalnych zarejestrowanych przez Unesco przekraczyła 7 tys., indywidualnych ok. 25 tys., polskich ponad 630 wg. H. Dryzek, Dzialalność Instytutu INTE na rzecz środowiska informacyjnego. „Przegląd Biblioteczny” 1993 z.1/2 s.100-101. Zob też W. Szczęch, Pakiet programów MicroISIS i możliwości jego uykorzystania w dydaktyce [w:] Z problemów metodologii i dydaktyki bibliotekoznawstwa i informacji naukowej, red. M.Kocójowa, Kraków 1990, s.151-164.

'Przewodnik po zbiorach rękopisów w Wilnie. Oprac. M.Kocójowa, Kraków 1993, 359 ss [cytat s.V-VI]..

${ }^{10}$ M. Kocójowa, Polonica w bibliotekach litewskich. [w:] XV Sesja Stalej Konferencji Archiwów, Bibliotek i Muzeów Polskich na Zachodzie 23-26. 09. 1993, Rzym 1994, s.9098. Wspominałam tam o podjęciu prac informacyjnych przez amerykankę Patrycję Kennedy Grimsted (1981- omówienie zasobów archiwalnych w Rosji; 1991 r. - zapoczątkowana seria nr 2: Estonia. Latvia, Lithuania, Belorusia)

${ }^{11}$ R. Cybulski, Miłe miasto, maszynop.: grudzień 1997 - dziękuję Autorowi za uprzejmie udostępnienie.

${ }^{12}$ Przykładem takich przedsięwzięć może być demonstrowana opracowywana w Information International Library and Analitic Center, Moskwa - baza multimedialna o sławnych miejscach w Rosji i archiwach, pokazywana na telekonferencji Emporia State University, USA nt „Information and Restructuring for Democracy” w listopadzie 1997 (adres bazy: shra@gpntb.msk.su).

${ }^{13}$ Bazy danych w Internecie adres od 1998 r.: http://www.miks.uj.edu.pl/wilno/ 